\title{
Paradox of Food and Nutrition Insecurity in Food Surplus Area of Haramaya District, Eastern Ethiopia
}

\author{
Daniel Alemu ${ }^{1, a, *}$, Anbesse Girma ${ }^{2, b}$ \\ ${ }^{1}$ Haramaya Institute of Technology, Food Technology and Process Engineering, Ethiopia \\ ${ }^{2}$ Haramaya Institute of Technology, Food Science and Postharvest Technology, Ethiopia \\ * Corresponding author
}

\begin{tabular}{|c|c|}
\hline A R T I C L E I N F O & A B S T R A C T \\
\hline $\begin{array}{l}\text { Keywords: } \\
\text { Food consumption habit } \\
\text { Food and nutrition insecurity } \\
\text { Paradox } \\
\text { Haramaya } \\
\text { Ethiopia }\end{array}$ & $\begin{array}{l}\text { Food and nutrition insecurity are inability to access adequate amount of nutritious foods to meet } \\
\text { dietary needs for a productive and healthy life. However, food and nutrition insecurity, in some part } \\
\text { of Ethiopia, is very high though food is not scarce. Therefore, a survey was conducted to investigate } \\
\text { food consumption and dietary habits of the population in the district. A questionnaire and focus } \\
\text { group discussions were used for data collection. Data were collected on available food sources and } \\
\text { habits of consumption in purposively selected four kebeles in the district. Data were specifically } \\
\text { collected on utilization and eating habit of cereal grains, legumes, fruit, vegetables, and animal food } \\
\text { sources. A total of } 150 \text { representative sample households were interviewed based on the population } \\
\text { size of the study area. The result obtained from the survey indicated that cereal grains (34.9\%), } \\
\text { legumes \& pulses ( } 28.5 \%) \text {, fruit \& vegetables (16.8\%), meat and poultry (19.8\%) products are } \\
\text { commonly produced in many parts of the study area. The study indicated that the population entirely } \\
\text { consumes cereal grains that are mainly sources of carbohydrate, with minimal consumption of other } \\
\text { food types. Though there are surplus food items in the study area, there is poor utilization and } \\
\text { undiversified consumption habit. This indicates that the area is vulnerable for food and nutrition } \\
\text { insecurity. Therefore, knowledge on proper utilization of local existing food sources for enhancing } \\
\text { food and nutrition security is essential. Awareness creation on benefits and preparation of balanced } \\
\text { diet at household level from local food sources is a vital to improve food and nutrition security in } \\
\text { the study area. }\end{array}$ \\
\hline
\end{tabular}

\section{Introduction}

Food security exists when all people at all times have physical or economical access to sufficient, safe and nutritional food to meet the dietary needs and food preference for an active and healthy life (FAO, 2008). Thus, food and nutrition insecurity is the inability to meet the required consumption levels at the time of fluctuating production, prices and incomes as well as poor market (Sidhu et al., 2008).

The achievement of food security depends upon four different but interrelated factors. The first is food availability which refers to insuring sufficient quantity and diversity of food. The second is food accessibility which refers to having physical and financial resources required to obtain foods. The third is food utilization which implies a capacity to use and store food appropriately to support healthy diet and the fourth is food stability (USAID, 1992).
United Nation reported that Ethiopia is the poorest country and vulnerable to severe food insecurity (European-commission, 2017). Ethiopian farmers do not produce enough food even in good rainfall years to meet consumption requirements. In many parts of Ethiopia, the main triggers of food insecurity are mainly drought, postharvest loss and lack of proper utilization.

However, food and nutrition insecurity, in some part of Ethiopia, is very high though food is plenty (Devereux, 2000). There is a production of cereal, legumes and pulses, fruit, vegetables and khet in eastern Hararghe zone. It is reported that the availability of a food in an area could not guardant for food secured society (Sidhu et al., 2008).

Therefore, it is important to understand the reason for food and nutritional insecurity in a food surplus area such as Haramaya district. 


\section{Materials and Methods}

\section{Description of the Study Area}

East Hararghe Zone, located in the Oromia Regional State, consists of 17 districts among which Haramaya district is one. The district lies at $42^{\circ} 30^{\prime} \mathrm{E}$ longitude and $9026^{\prime} \mathrm{N}$ latitude. It is located $18 \mathrm{~km}$ away from Harar town and about $508 \mathrm{~km}$ east of the capital city, Addis Ababa. The mean annual rainfall is $492 \mathrm{~mm}$, which varies between 118 and $866 \mathrm{~mm}$.

\section{Approach and Data Collection}

A general survey model was used to collect data through a questionnaire which included series of openended questions. The field data collection involved a combination of qualitative and quantitative descriptive surveys. Data gathering was conducted on food availability and utilization and eating frequency per day. Data collection were conducted randomly in selected kebeles (Damotta, Finqile,Tinke and GandaLafe) around Haramaya University. Each kebele contains an estimated population of about 2000 (Haramaya district administrative office). A total of 150 representative sample households were interviewed based on the population size of the study area (Hamed, 2017). Simple descriptive statistics were used to express frequency and make simple comparisons.

\section{Results and Discussions}

\section{Food Availability}

Cereal grains are the most important agricultural crops available in the area accounting $34.9 \%$ of the total foods at the household level (see Figure 1). The common cereal grains in the area are sorghum and maize which is obtained from subsistent own-farm production and purchase from the market.

Grains are energy dense food sources with about 1020 times more energy than from fruit and vegetables (Sidhu et al., 2007). They are important sources of dietary protein, carbohydrates, the B complex of vitamins, vitamin E, iron, trace minerals and fiber (Demissie et al., 2009). It has been estimated that global grain consumption directly provides about $50 \%$ of the protein and energy necessary for the human diet (Mkumbwa, 2012). Consumption of whole grain is more important than consuming the refined flour due to high minerals and fiber content of the hull and bran (Courtin, 2014).

Legumes and pulses share $28.5 \%$ of the total foods available in the study area. Availability of fruit and vegetables in the area is around $16.8 \%$, while the meat and poultry share $19.8 \%$.

\section{Food Utilization in the Study Area}

According to Goldschmidt et al. (2009) the concept of sustainable diversified diets presents development and the elimination of poverty, food and nutrition insecurity, and poor health outcomes.

As indicated earlier, production of cereal grain is high. As a result, the majority of the community (65.4\%) uses cereals in a regular basis for household consumptions. The common household food types prepared from cereals are Buddena (Injera), Shumo (boiled grain), Marqa (porridge),
Kita (unfermented bread), danfa (stew) and Kolo (toasted grain). To fulfill daily nutritional requirements, consumption of cereals solely is not enough, and the community doesn't have much habit of mixing cereals for better nutrient (see Figure 2). Among the respondents, only $15.4 \%$ of them were involved in mixing habit in a regular basis while $84.6 \%$ do not. Even the existing mixing habits add no extra nutrients to the food due to improper raw material selection. Dietary diversity can be used as proxy indicators for food and nutrition security, which may be due to its ability to capture consumption of both macro and micronutrients or a more balanced diet (Allen, 2003). Though there are surplus cereal food items in the area, the community lacks proper utilization and diversified diet.

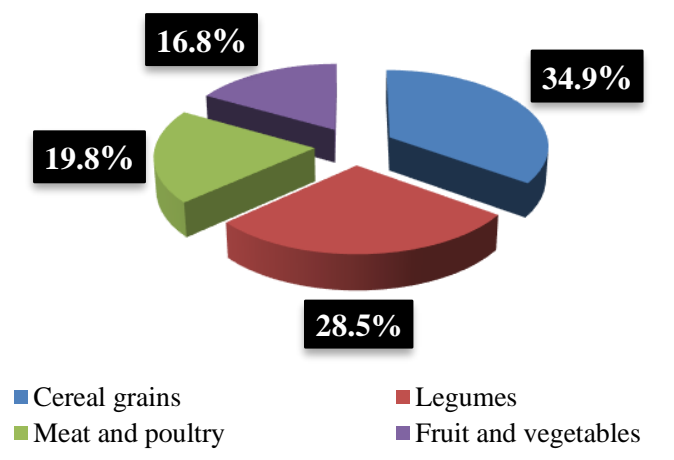

Figure 1 Major food items available in the study area

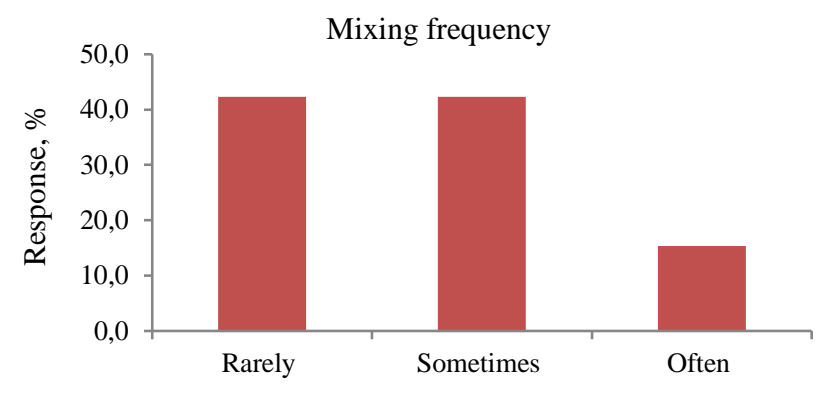

Figure 2 Mixing habit of cereal grains with other food for better nutritional food

Majority (54.2\%) of the respondents uses pulses and legumes once or twice a month and the remaining (37.5\%) use occasionally for consumption. According to the respondents, most of them took to the market for income generation. Products are rarely prepared for household consumptions such as Shumo (local language for boiled grain and legumes mixes) and danfa (local name for stew).

Legumes and pulses contain high amounts of protein and other important components (Kabataet al., 2017) ). Most of the proteins are water-soluble, functional proteins as distinct from storage protein. According to most literatures, legumes and pulse are among the food staffs for which regular consumption is highly recommended (Leterme, 2008). Gibson et al, (2009) also explained that, including legume and pulse in the diet helps to provide a range of nutrients They are the best non meat sources of minerals such as iron providing about $30 \%$ of the daily requirement (Pachico, 1993). Legumes and pulses contain nutrients which are lacking in cereal grains, therefore, incorporating these food items in households' menu is important. 
Many of the respondents (36\%) do not consume fruit and vegetables as part of their diet, only $32 \%$ of them are consuming in a regular base. The inhabitants of the study area are more focused on taking fruits and vegetables to the market. Moreover, consuming a diet high in fruit and vegetables is associated with lower risks for numerous chronic diseases, including cancer and cardiovascular disease (Conner, et al., 2017; Oyebode, et al., 2013; Boffetta, et al., 2010;Kader, 2001)

The community (72\%) consumes meat and poultry products once a month, whereas only $8 \%$ of them consume on a regular basis. Rather than consuming milk and eggs, the majority of the community prefer to sells to the market. Due to this, the consumption of these products is minimal in the study area even though it provides essential nutrients to the households.

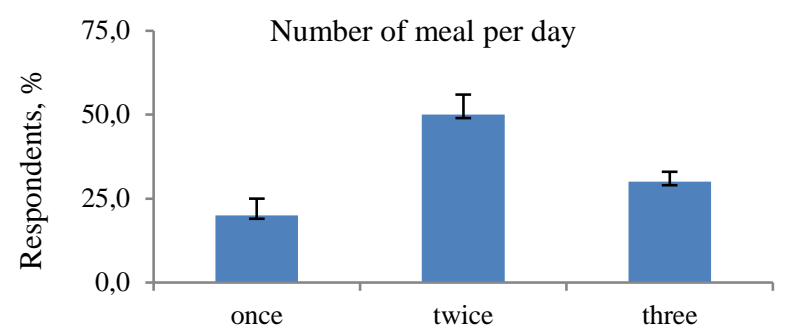

Figure 3 Number of meals consumed by the respondents within 24 hours

Many of the respondents (50\%) have two meal per day while the other have once $(20 \%)$ and twice $(30 \%)$ within 24 hours (see Figure 3). As indicated earlier, the community mainly consumes cereal based food products with small amount per meal. This shows that having once or twice meals per day is not guaranteed to fulfill the daily requirement. In the study area, there is high production of that (stimulant leave) and many of them are addicted. Due to this, their appetite can be diminishing. In a society where cereals are the major food, it is difficult to maintain the daily requirement unless food is diversified and the habit of consumption is improved (Unu, 2007).

\section{Conclusion}

Cereal grains, legumes, pulses, fruit, vegetables, meat and poultry products are commonly produced in many parts of the study area. Though there are surplus food items, there is poor utilization and undiversified consumption habit. It is concluded that the availability of a food in an area could not guardant for food and nutrition security. As a consequence, the community is exposed to food and nutrition insecurity.

Therefore, it is recommended to create awareness on proper utilization of food and benefits of diversified food consumption to enhance food and nutrition security.

\section{Acknowledgements}

The authors thank the households who were kind enough to allow us into their house and provide information. The authors thank who involved in data collection and assisted us during the field campaign. The authors also thank the editorial board and an anonymous reviewer for their assistance. This study was funded fully by the Haramaya University through community engagement office.

\section{References}

Allen LH. 2003.Interventions for micronutrient deficienc $\backslash$ control in developing countries: Past, present and future. J Nutr 133: 3875S-3878S.

Boffetta P. Couto E. Wichmann J. Ferrari P. Trichopoulos D. Bueno-de-Mesquita HB. 2010. Fruit and vegetable intake and overall cancer risk in the European Prospective Investigation into Cancer and Nutrition (EPIC). Journal of the National Cancer Institute. 2010 Apr 21;102(8):529-537. DOI: 10.1093/jnci/djq072. PMID: 20371762

Chauvin ND. Mulangu F, Porto G. 2012. Food Production and Consumption Trends in Sub-Saharan Africa. Prospects for the Transformation of the Agricultural Sector.

Conner TS. Brookie KL. Carr AC. Mainvil LA. Vissers MCM. 2017. Let them eat fruit! The effect of fruit and vegetable consumption on psychological well-being in young adults: A randomized controlled trial. PLoS One. 2017;12(2): e0171206. DOI: 10.1371/journal.pone.0171206

Devereux S. 2000.Food Insecurity In Ethiopia A discussion paper for DFID, Ethiopia.

European commission. 2017. Eurostat Handbook for Annual Crop Statistics (Regulation (EC) No 543/2009. Commission Delegetad Regulation (EU) 2015/1557 and ESS agreement for Annual Crop Statistics. Revision 2017. Released 9 February 2017.

FAO. 2018. Dietary Assessment: a resource guiDe to method selection and application in low resource settings Food, Rome.

FAO. 2008. Climate change and food security: Aframe work document. Rome. Accessed 2 December 2008.

FAO. 2008. Climate change and food security: a framework document. Rome. http://www.fao.org/fores try/15538 -079b3 1d450 81fe9 c3dbc 6ff34 de480 7e4.pdf.Accessed 2 Dec 2017.

Goldschmidt AB, Grange D, Le, Powers P, Crow SJ, Hill LL, Peterson CB, Crosby RD, Mitchell JE. 2009. Eating Disorder Symptomatology in Normal-Weight vs. Obese Individuals with Binge Eating Disorder. Obesity, 19, 1515-1518.

Hamed T. 2017. Determining Sample Size; How to Calculate Survey Sample Size 1 Survey Sample Size. Int. J. Econ. Manag. Syst., 2, 237-239.

Kabata A, Henry C, Moges D, Kebebu A. Whiting S, Regassa N. 2017. Determinants and Constraints of Pulse Production and Consumption among Farming Households of Ethiopia, 6, 41-49.

Kader A. 2001. Importance of fruits, nuts, and vegetables in human nutrition and health. Perishables Handl. Q., 4.

Lawrie RA, Ledward DA. 2006. Meat science SEVENTH ED., England: Woodhead Publishing Limited, Abington Hall, Abington Cambridge CB1 6AH, England.

Leterme P. 2002.Recommendations by health organizations for pulse consumption. Br. J. Nutr. 2002, 88, S239-S242.

Oyebode O. Gordon-Dseagu V. Walker A. Mindell JS. 2014. Fruit and vegetable consumption and all-cause, cancer and CVD mortality: Analysis of Health Survey for England data. Journal of Epidemiology and Community Health. 2014 Mar 31: jech-2013

Pachico D.1993. The demand for bean technology. In G. Henry (Ed.). Trends in CIAT commodities. Cali, Colombia: Centro International de4 Agricultura Tropical (CIAT), 1993.

Piguet, F. 2003. Hararghe Food Security hampered by long-term drought conditions and economic constraints. UN Rep., 1-14.

Sidhu RS, Kaur I, Vatta K. 2008. Food and Nutritional Insecurity and its Determinants in Food Surplus Areas: The Case Study of Punjab State. Agric. Econ. Res., 21, 91-98.

Unu WHOFAO. 2007. Protein and Amino Acid Requirements In Nutrition a of Joint, Geneva, Switzerland.

USAID.1992. Policy Determination of for definition of food security. Available from: [http://www.usaid.gov/policy/ads /200/pd19.pdf] 